\title{
Effects of immune complexes from SLE patients on human monocyte locomotion and Fc receptor function
}

\author{
KATALIN LUKÁCS, * MARIA KÁVAI, ANIKÓ BÁNYAI, ILDIKÓ SONKOLY, \\ ÉVA VÉGH, GYÖNGYI SZABÓ, AND GY. SZEGEDI \\ From the IIIrd Department of Medicine, University Medical School of Debrecen, Debrecen, Hungary
}

SUMmaRY The effect of immune complexes (IC) isolated from systemic lupus erythematosus (SLE) sera with polyethylene glycol and gel filtration on the chemotaxis and Fc receptor function of healthy monocytes was examined. Even at a low protein concentration $(1 \mu \mathrm{g} / \mathrm{ml}=1 \mathrm{mg} / \mathrm{l}) \mathrm{ICs}$ inhibit monocyte chemotaxis. ICs from patients with SLE nephritis are more inhibitory than ICs from patients without renal disease. The inhibitory effects of ICs on monocyte chemotaxis and Fc receptor activity are similar, suggesting a relationship between the chemotactic and Fc receptor function of monocytes. Analysis of the ICs by enzyme-linked immunoassay showed no correlation between the quantity of IgG, C3, and anti-DNA in the IC samples and their effects on monocyte function.

Key words: Receptors immunological, monocytes, autoimmune diseases, antigen-antibody complex.

It is well known that surface-bound, immobilised immune complexes (IC) inhibit the reaction of sensitised erythrocytes (EA) with macrophage Fc receptors. ${ }^{1}$ The expression of several other plasma membrane receptors is only slightly affected by the first reaction of $\mathrm{Fc}$ receptors with immobilised or particulated IC. ${ }^{12}$ On the other hand some data indicate that surface-bound IC can inhibit polymorphonuclear leucocyte (PMNL) locomotion. ${ }^{3}$

Our results, ${ }^{4}$ which agree with the findings of Griffin, ${ }^{5}$ provide strong evidence that not only immobilised but also soluble IC block monocyte Fc receptors. And Kay and his co-workers ${ }^{6}$ have reported that phagocytosis mediated by Fc receptors diminished the subsequent chemotaxis of PMN leukocytes.

In our earlier study an impairment of monocyte chemotaxis was found in patients with SLE. ${ }^{7}$ In this study the effect of soluble ICs isolated from sera of SLE patients is examined in vitro on Fc receptor

\footnotetext{
Accepted for publication 3 May 1984.

*Present address: Albert B. Chandler Medical Center, College of Medicine, Department of Medical Microbiology and Immunology, University of Kentucky, Lexington, KY 40506-0084, USA. Correspondence to Professor Gy. Szegedi, IIIrd Department of Medicine, University Medical School of Debrecen, Debrecen 4004, Hungary
}

function as well as on chemotaxis of healthy monocytes. The aim of these experiments is to support in vitro the possibility that the ICs in the sera of patients with SLE may have some role in the impairment of monocyte functions. On the other hand the question arises whether there is some relation between the Fc receptor function and the locomotion of monocytes.

\section{Materials and methods}

Patients. Forty-nine sera from 26 patients with SLE were tested ( 23 females and 3 males). The patients fulfilled the preliminary ARA criteria for SLE. ${ }^{8}$ Twenty four of the sera were derived from patients with active disease. Disease activity was defined by the presence of arthritis, serositis, nephritis, skin rash, high fever, hypocomplementaemia, and high ds-DNA binding activity. In the case of 15 patients (29 sera) the SLE nephritis was confirmed by laboratory tests and by renal biopsy. Patients with a uraemic clinical picture and laboratory data were excluded.

Preparation of immune complexes from sera of SLE patients and of 20 healthy donors. $7 \%$ polyethylene glycol (PEG) was added in equal 
quantities to $5 \mathrm{ml}$ sera, which was diluted 25 times with a borate-buffer, $\mathrm{pH}: 8 \cdot 4$. After standing at $4^{\circ} \mathrm{C}$ for $24 \mathrm{~h}$ the mixture was centrifuged at $3000 \mathrm{~g}$. The precipitates were washed and dissolved in $2 \mathrm{ml}$ of phosphate buffered saline (PBS) and filtered on ultragel AcA 34. The protein concentration of the 2 $\mathrm{ml}$ eluted and concentrated solution of IC was determined by the Lowry method.

Separation of monocytes. Human monocytes were obtained by the method of Nakagawara et al ${ }^{10} 15 \mathrm{ml}$ of heparinised venous blood, taken from healthy donors, was sedimented on Ficoll-Uromiro gradients. After being washed the cells were suspended in Parker's medium, which also contained $10 \%$ fetal calf serum and $20 \mathrm{mM}$ HEPES, and counted in a standard haemocytometer. A trypan blue exclusion test and non-specific esterase staining ${ }^{11}$ were performed to determine percentages of viable (90$95 \%)$ and phagocytic mononuclear cells (35-45\%) respectively.

Chemotaxis test. Chemotaxis assays were performed by a modification of the Boyden chamber technique. ${ }^{12} 0.5 \times 10^{6}$ monocytes in a $0.5 \mathrm{ml}$ medium with a zymozan (Sigma) activated complement derived chemotactic factor and $5 \mu \mathrm{m}$ pore size Millipore filter (Sartorius Membranfilter, $\mathrm{GmBH}$, Göttingen) were used in every chemotaxis test. After being filled the chambers were incubated at $37^{\circ} \mathrm{C}$ for $90 \mathrm{~min}$. The filters were stained with haematoxylin and evaluated microscopically by measuring the distances travelled by all of the moving cells in five microscopic fields. The lymphocyte contamination does not disturb the measuring of monocyte locomotion.

After dose-response experiments the effect of ICs on chemotaxis was tested by adding $1 \mu \mathrm{g} / \mathrm{ml}(1 \mathrm{mg} / \mathrm{l})$ of each IC sample to $10^{6}$ monocytes in $1 \mathrm{ml}$ medium and incubating for $30 \mathrm{~min}$ at $37^{\circ} \mathrm{C}$. The monocytes were washed twice before putting into the chemotactic chambers. The results were expressed as inhibition percentage compared with the controls without the IC.

Monocyte EA rosette. The monocyte $\mathrm{Fc}$ receptor (FcR) activity was assayed by the uptake of sheep red blood cells (SRBC) coated with a subagglutinating dilution of an IgG fraction isolated from rabbit anti-SRBC serum on Sephadex G-200. The monocytes, adherent to a glass slide $\left(1 \cdot 5-2 \times 10^{5}\right.$ cells $)$, were incubated with $0.2 \mathrm{ml}$ of $2 \%$ sensitised SRBC (EA) in $0.3 \mathrm{ml}$ of Parker's medium at $37^{\circ} \mathrm{C}$ for 30 min. After being washed the percentage of cells attaching and/or ingesting three or more EA was determined.

The effect of isolated ICs on the subsequent phagocytosis of EA was tested by adding $0 \cdot 1-5$ $\mu \mathrm{g} / \mathrm{ml} \mathrm{(mg/l)}$ of each IC sample to the adherent monocytes and incubating at room temperature for $30 \mathrm{~min}$ in $0.5 \mathrm{ml}$ medium. The results were expressed as IC $\mu \mathrm{g}$ protein necessary for $50 \%$ inhibition of subsequent uptake of EA. ${ }^{4}$

Analysis of isolated immune complexes. An enzyme-linked immuneassay (ELISA) was applied to analyse the isolated IC samples. The samples were placed in 96-well polystyrene (Linbro) microtitre plates. The quantity of the immune globulins and $\mathrm{C} 3$ in the samples was measured with antihuman $\mathrm{IgG}$ and $\mathrm{C} 3$ conjugates (Dako) labelled with peroxidase.

To determine the anti-DNA Ig the polystyrene plates were coated with methylated bovine serum albumin (BSA). Methylated BSA can fix DNA molecules, ${ }^{13}$ the antigen component of the DNA anti-DNA complexes. Non-fixed ICs were removed by washing. The anti-DNA Igs were measured with peroxidase conjugated anti-human Igs.

Statistical analysis. The mean values of data as well as the standard deviation (SD) were calculated with a computer. The correlation coefficients ( $r$ ) were calculated from the straight line equation. All curve fitting was done by the least squares method. The statistical significance of the difference between the groups was calculated by Student's $t$ test.

\section{Results}

Immune complexes precipitated from SLE sera inhibited the chemotaxis of normal monocytes. At

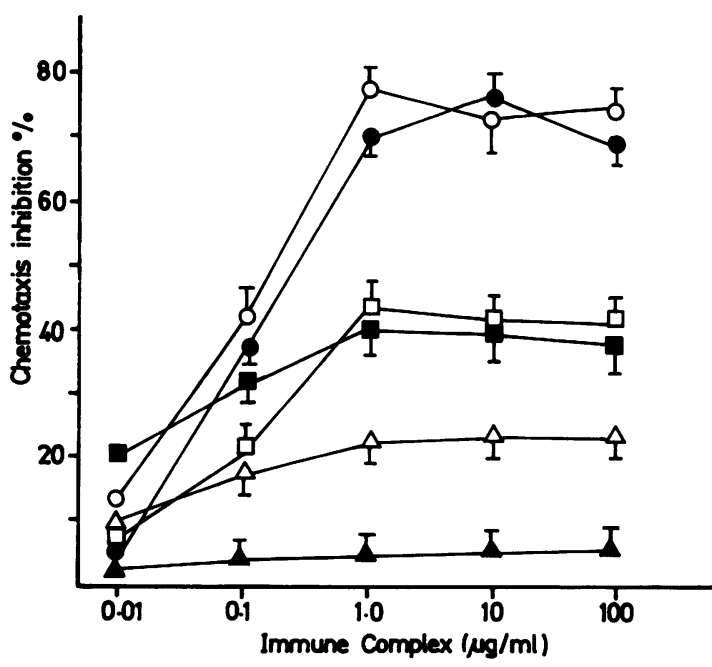

Fig. 1 Effect of immune complexes separated from the sera of five $S L E$ patients $(\bigcirc, O, \square, \square, \triangle)$ and from $a$ normal pooled serum ( $\triangle$ ) by $P E G$ precipitation and gel filtration on the chemotaxis of normal human monocytes at different protein concentrations. 
low concentrations this inhibition showed a doseresponse curve, but the inhibition effect was maximal at $1 \mu \mathrm{g}$ protein/ml IC (1 mg/l) (Fig. 1). The PEG precipitates, prepared in the same way from a normal sera, showed no significant inhibition. The degree of maximal inhibition varied considerably with ICs from different SLE patients.

The ICs from patients with SLE nephritis inhibited chemotaxis significantly more than the ICs from patients without any renal manifestation (Table 1). In contrast disease activity did not alter the effect of the ICs on the monocytes.

The effect of 30 isolated IC samples on monocyte FcR activity was also examined. A $50 \%$ inhibition of FcR activity was produced by an IC concentration of $1.01 \pm 0.55 \mu \mathrm{g} / \mathrm{ml}$ (mean $\pm \mathrm{SD}$ ).

The inhibitory effect of the ICs' monocyte chemotaxis and Fc receptor activity were highly correlated ( $\mathrm{r}=0.898)$ (Fig. 2).

The isolated ICs were analysed by an ELISA method (Table 2) to test for a correlation between

Table 1 Relationship of chemotaxis inhibition caused by immune complexes from SLE patients with renal disease and disease activity

\begin{tabular}{lcc}
\hline & $\begin{array}{l}\text { Chemotaxis inhibition } \\
\% \pm S D\end{array}$ & Significance \\
\hline $\begin{array}{l}\text { Renal manifestaion } \\
\text { Present } \mathrm{n}=29\end{array}$ & $61 \cdot 55 \pm 15 \cdot 33$ & \\
Absent $\mathrm{n}=20$ & $39 \cdot 88 \pm 16 \cdot 34$ & $\mathrm{p}<0.01$ \\
Activity of the disease & \\
Present $\mathrm{n}=24 \quad 56.92 \pm 18 \cdot 12$ & \\
Absent $\mathrm{n}=25$ & $50 \cdot 25 \pm 18.60$ & $\mathrm{p}<0.30$
\end{tabular}

Immune complexes were separated from SLE sera by $3.5 \%$ PEG precipitation and gel filtration.

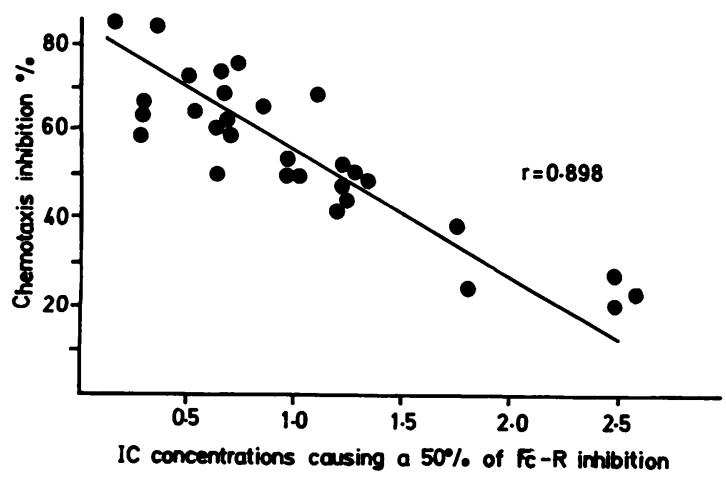

Fig. 2 Correlation between the effect of the immune complexes from SLE patients on the chemotaxis and on the $F c$ receptor function of healthy donors.
Table 2 Analysis of isolated ICs by ELISA

\begin{tabular}{|c|c|c|c|c|c|c|}
\hline \multirow[t]{2}{*}{ IC samples } & \multirow[t]{2}{*}{$\begin{array}{l}\lg G \\
(\mu g / m l \pm\end{array}$} & \multirow[t]{2}{*}{$\begin{array}{l}\operatorname{Ig} A \\
S D)\end{array}$} & \multirow[t]{2}{*}{$\operatorname{Ig} M$} & \multirow[t]{2}{*}{$C 3$} & $\operatorname{Ig} G$ & $\lg M$ \\
\hline & & & & & \multicolumn{2}{|c|}{$\begin{array}{l}\text { in DNA-anti- } \\
\text { DNA complex }\end{array}$} \\
\hline $\begin{array}{l}\text { From SLE } \\
\text { patients } \\
\mathbf{n}=30\end{array}$ & $\begin{array}{r}102 \cdot 5 \\
\pm 59 \cdot 3\end{array}$ & $\begin{array}{r}19.2 \\
\pm 15.8\end{array}$ & $\begin{array}{r}32 \cdot 5 \\
\pm 22 \cdot 1\end{array}$ & $\begin{array}{r}0.84 \\
\pm 1.20\end{array}$ & $\begin{array}{r}0.99 \\
\pm 0.68\end{array}$ & $\begin{array}{r}0 \cdot 16 \\
\pm 0 \cdot 13\end{array}$ \\
\hline $\begin{array}{l}\text { From healthy } \\
\text { donors } \\
n=20\end{array}$ & $\begin{array}{c}4 \cdot 40 \\
\pm 0 \cdot 45\end{array}$ & $\begin{array}{r}0.75 \\
\pm 0.12\end{array}$ & $\begin{array}{r}5.44 \\
\pm 0.43\end{array}$ & ND & ND & ND \\
\hline
\end{tabular}

$\mathrm{ND}=$ non-detectable.

the effect of the ICs on the monocyte function and their content of immunoglobulin, C3, and antiDNA. The inhibitory effect of the ICs on the monocyte chemotaxis depended only slightly $(r=0.33)$ on their IgG content (Fig. 3). The degree of the inhibition was determined neither by the $\mathrm{C} 3$ content $(r=0.20)$ nor by the quantity of anti-DNA content $(r=0 \cdot 13)$.

The greatest inhibition of monocyte chemotaxis was seen when ICs were present during the chemotaxis test (Table 3 ). When the ICs were removed

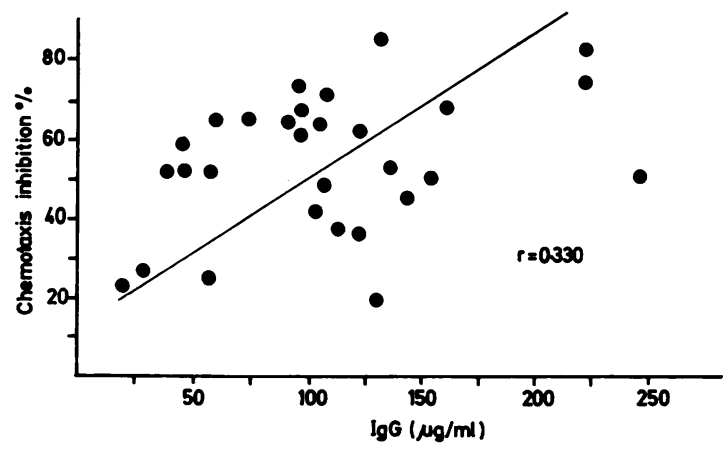

Fig. 3 IgG content of the immune complexes from $S L E$ patients and their effect on the monocyte chemotaxis.

Table 3-Inhibitory effect of immune complexes on monocyte chemotaxis after different incubation periods

\begin{tabular}{ll}
\hline Chemotaxis & Inhibition $\% \pm S D$ \\
\hline Without washing (IC present) & $78 \cdot 6 \pm 8 \cdot 4$ \\
After washing & $36 \cdot 0 \pm 4 \cdot 8$ \\
1 h after washing & $25 \cdot 3 \pm 5 \cdot 3$ \\
3 h after washing & $21 \cdot 0 \pm 4 \cdot 5$ \\
4 h after washing & $0 \cdot 0 \pm 8 \cdot 7$
\end{tabular}

$10 \% / \mathrm{ml} \mathrm{monocyte}+1 \mu \mathrm{g} / \mathrm{ml}(\mathrm{mg} / \mathrm{l})$ of immune complexes were preincubated for $\mathbf{3 0} \mathrm{min}$ and washed twice before further incubation at $37^{\circ} \mathrm{C}$. 
after 30 min of preincubation, the degree of inhibition decreased. A four-hour incubation period of the monocytes at $37^{\circ} \mathrm{C}$, after removal of the IC, was enough to stop the inhibition.

\section{Discussion}

In experiments presented in this paper the immune complexes isolated from SLE sera inhibited the chemotaxis of healthy monocytes. In separate experiments the possibility that ICs themselves exert a chemotactic activity for monocytes, thereby causing a counter-concentration gradient opposite to the chemotactic factor, was excluded. Data similar to ours were reported by Kay and his co-workers ${ }^{6}$ : phagocytosis mediated by FcR diminished the subsequent chemotaxis of PMN leucocytes.

The data in this paper demonstrate that the inhibitory effects of ICs on monocyte chemotaxis and on FcR function are correlated. Since integrity of the $\mathrm{Fc}$ fragment of the $\mathrm{IgG}$ is required in aggregated IgG for the inhibition of both the FCR-mediated phagocytosis and the locomotor capacity of PMN leucocytes, ${ }^{14}$ we examined the role of the IgG content of the ICs on their inhibitory effects. The correlation coefficient was small. As it is known that the inhibitory effect of soluble IC on the subsequent FcR-mediated phagocytosis is dependent on the composition, the antibody-antigen ratio, and the antibody avidity of the $\mathrm{IC},{ }^{4}$ a closer correlation could not be expected between the IgG content of the isolated ICs and their inhibitory effect. The anti-DNA and C3 content of ICs was not correlated with their inhibitory effects.

The chemotaxis inhibitory effect of the ICs from different SLE patients showed considerable differences. The ICs isolated from sera of patients with SLE nephritis inhibited chemotaxis to a significantly greater extent than ICs from patients without renal disease. The cause of the different effects may be differences of composition, size, and antibody avidity of ICs isolated from patients with different types of renal disease.

We conclude from these data that it is possible that monocytes coming into contact with ICs in the serum in vivo in patients with SLE are inhibited in their subsequent locomotion and FcR function.

Our results suggest a relationship between the locomotion and FcR function of monocytes. It is most probable that the soluble, isolated ICs inhibit the FcR-mediated phagocytosis competitively through binding to the same receptors. The decrease of monocyte chemotaxis may occur through inhibition of chemotactic or locomotor receptor by ICs. However, it is most likely that the ICs, like aggregated IgG, may cause a modification of the cells to the substrate, which may impair the locomotor capacity of the cells. ${ }^{14}$ The membrane alteration caused by the FcR-IC interaction contributes to the modification of cell adhesion. ${ }^{15}$ After four hours' incubation of monocytes apart from ICs the inhibitory effect was abolished, presumably because of the regeneration of cell membrane. ${ }^{2}$

\section{CONCLUSION}

Our data show that ICs isolated from the sera of patients with SLE can inhibit both the locomotor capacity and FcR function of monocytes of normal, healthy individuals in vitro. As the level of circulating immune complexes is well known to be raised in SLE, these in-vitro effects support the possibility that the ICs in sera of patients with SLE may be of pathological importance.

This work was supported by the National Foundation for Cancer Research, Bethesda, MD, USA.

\section{References}

1 Michl J, Piechenka M M, Unkeless J C, Silverstein S C. Effects of immobilized immune complexes on Fc- and complementreceptor function in resident and thioglycolate-elicited mouse peritoneal macrophages. J Exp Med 1979; 150: 607-21.

2 Mellman I S, Plutner H, Steinman R M, Unkeles J C, Cohn Z. Internalization and degradation of macrophage $\mathrm{Fc}$ receptors during receptor-mediated phagocutosis. J Cell Biol 1983; 96: 887-95.

3 Dahlgren C, Elwing $H$. Inhibition of polymorphonuclear leukocyte locomotion by surface-bound antigen-antibody complexes. Immunology 1983; 49: 329-36.

4 Kávai M, Sándor M, Szegedi Gy, Füst G, Gergely J. Effect of soluble immune complexes on Fc and $\mathrm{C} 3$ receptor-dependent phagocytosis by human monocytes. Immunology 1981; 44: 599-6.

5 Griffin F M Jr. Effects of soluble immume complexes on Fc receptor and $\mathrm{C} 3$ receptor-mediated phagocytosis by macrophages. J Exp Med 1980; 152: 905-19.

6 Kay N E, Bumol T F, Douglas S D. Effect of phagocytosis and Fc receptor occupancy on complement dependent neutrophil chemotaxis. J Lab Clin Med 1978; 91: 850-6.

7 Szegedi Gy. Immunological investigations in systemic lupus erythematosus. Panminerva Med 1978; 20: 9-22.

8 Cohen A S, Reynolds W E, Franklin E C, et al. Preliminary criteria for the classification of systemic lupus erythematosus. Bull Rheum Dis 1971; 21: 643-71.

9 Digeon M, Laver M, Riza J, Bach J F. Detection of circulating immune complexes in human sera by simplified assays with polyethylene glycol. J Immunol Methods 1977; 16: 165-84.

10 Nakagawara $\mathrm{A}$, Nathan $\mathrm{C} F$, Cohn $\mathrm{Z}$ A. Hydrogen peroxide metabolism in human monocytes during differentiation in vitro. J Clin Invest 1981; 68: 1243-51.

11 Manconi P E, Marrosu M G Pagki P, Correale G, Zaccheo D. $\alpha-N E$ activity in human lymphocytes: distribution in lymphocyte subpopulations in mitogen-activated cells. Scand $\mathrm{J} / \mathrm{m}$ munol 1979; 9: 99-104.

12 Lukács K, Berényi E, Kávai M, Szegedi Gy, Szekerke M. Potentiation of the defective monocyte chemotaxis in Hodgkin's disease by in vitro tuftsin treatment. Cancer Immunol Immunother 1983; 15: 162-3. 
13 Kávai M, Bányai A. Zsindely A. Sonkoly I, Szegedi Gy. Enzyme-linked immunosorbent assay for antibodies to native DNA in sera of patients with SLE. J Immunol Methods 1982; 48: $169-75$.

14 Wilkinson P C. Effects of human IgG on locomotion of human neutrophils related to IgG binding of a hydrophobic probe. Immunology 1980; 41: 457-66.

15 Keller H U. Barandun S, Kistler P. Ploem J S. Locomotion and adhesion of neutrophil granulocytes. Exp Cell Res 1979; 122: 351-62. 